\title{
EDITORIAL
}

\section{Variations on a Theme by Darwin}

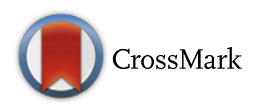

Mark E. Sobel

From the American Society for Investigative Pathology, Rockville, Maryland

\section{Variations on a Theme by Darwin}

The biomedical scientist members of the American Society for Investigative Pathology (ASIP) observe, catalog, decipher patterns, design experiments to test hypotheses, and develop theories to understand pathobiological processes. When I was appointed ASIP Executive Officer in March 2001, I applied the same scientific processes I had used for 25 years in the laboratory to the administrative management of the Society. In 2001, the ASIP Executive Office also managed seven other organizations (Table 1) and subsequently managed others. Several years into my 17-year tenure as ASIP Executive Officer, I had an epiphany: namely, that I could treat each organization as a biological entity, each with its own genome and phenome, the compilation of the genomic predispositions and phenotypic expressions of their memberships. Furthermore, I realized that if I applied the principles of Darwin's theory of evolution $^{1}$ to the management of these entities, I might better promote their development and advancement.

Central tenets of the theory of evolution are that organisms must adapt to external conditions and diversity is essential for survival. It follows that variations in biomedical infrastructure and sources of funding will affect the individuals who become ASIP members, thus constantly changing the ome of the organization. The emphasis that ASIP has placed in the past two decades on diversity of its membership can be considered an example of the application of evolutionary gene theory.

I posit that the ASIPome can best be characterized as the synergy between creativity, rigorous scientific experimentation, and analysis, with a healthy dose of altruism. Although the concept of altruism and the selfish gene was initially met with skepticism and controversy when Richard Dawkins introduced it in $1976,{ }^{2}$ it has since gained more credibility in the scientific literature (https://explorable.com/ selfish-gene-theory, last accessed February 1, 2018). The selfish gene theory states that closely related individuals are more likely to have the same genes, and it makes evolutionary sense for them to behave selflessly with each other. ASIP members apply the selfish gene theory when they mentor and promote the career development of their colleagues.

Like departments of pathology and laboratory medicine in medical centers, which have a home in both the basic science departments of the medical school and the clinical departments of the hospital, ASIP is defined by its roots in basic science and clinical medicine. ASIP stands at the forefront of national and international pathology organizations in promoting translational research. Our evolutionary directive is to synergize basic, translational, and clinical scientific research for the betterment of all.

\section{Variations on a Theme by Fulghum}

In 1990, Robert Fulghum ${ }^{3}$ delineated lessons that we should have learned in kindergarten. After more than three decades of service to ASIP (Table 2), I offer 10 take-away lessons, some of which (designated below in bold) have been extrapolated from Fulghum. ${ }^{3}$

1. Always be cognizant of the mission of the Society: "to promote the discovery, advancement, and dissemination of basic and translational knowledge in experimental pathology and related disciplines."

2. Governing is a serious business. The Society was registered in 1968 as a 501(c)(3) nonprofit educational organization subject to laws and regulations. Net revenues of a nonprofit organization should be reinvested in programs that benefit the members and the mission of the Society.

3. Safeguard the resources of the Society but realize that you cannot make an omelet without breaking some

\footnotetext{
Accepted for publication February 6, 2018.

Disclosures: None declared.

Address correspondence to Mark E. Sobel, M.D., Ph.D., 1801 Rockville Pike, Suite 350, Rockville, MD 20852. E-mail: mesobel@asip.org.
} 
Table 1 Organizations Managed by ASIP from 2001 to 2018

\begin{tabular}{ll}
\hline Organizations & Years \\
\hline $\begin{array}{l}\text { Association for Molecular } \\
\quad \text { Pathology }\end{array}$ & $2001-2013$ \\
Association for Pathology & $2001-2008$ \\
$\quad$ Informatics & $2001-2012$ \\
Association of Pathology Chairs & $2001-2013$ \\
International Society for & \\
$\quad$ Biological and Environmental & \\
$\quad$ Repositories & $2001-2018$ \\
Intersociety Council for & \\
$\quad$ Pathology Information & $2001-2006$ \\
North American Vascular Biology & \\
$\quad$ Organization & $2006-2009$ \\
Pulmonary Pathology Society & $2001-2002$ \\
Universities Associated for & \\
$\quad$ Research and Education in & \\
$\quad$ Pathology &
\end{tabular}

eggs. Be fiscally conservative but do not be so frugal that you forego potential long-term benefits of wise investments in infrastructure and programs.

4. Recruit experts and surround yourself with individuals who have skill sets that complement your own. Recognize their weaknesses, and value their strengths.

5. Do not hit people. Treat people with dignity and respect.

6. Play fair. Character counts, and the truth matters. Be transparent and respect apparent, potential, or real conflicts of interest. The desired end does not justify the means.

7. Do not take things that are not yours. Respect scientific integrity and ensure that you do not violate the public's trust in the scientific process.

8. Clean up your own mess. Say you're sorry when you hurt somebody. Admit mistakes and errors, and take appropriate corrective action; however, when faced with
Table 2 History of Mark E. Sobel's Major ASIP Positions from 1987 to 2018

\begin{tabular}{ll}
\hline Years & ASIP positions \\
\hline $1987-1999$ & Director, Concepts in Molecular Biology Course \\
$1995-1997$ & Councilor, ASIP Council \\
$1997-1998$ & Vice President-Elect, ASIP Council \\
$1998-1999$ & Vice President, ASIP Council \\
$1999-2000$ & President, ASIP Council \\
$2000-2001$ & Past President, ASIP Council \\
$2001-2018$ & Executive Officer \\
2018 & Executive Officer Emeritus \\
\hline
\end{tabular}

baseless and irrational criticisms, do not be too defensive or you will risk getting sucked into the black hole of trying to fix unsolvable or imaginary problems. Recognize that we are sometimes the victims of the selfish and unethical thoughts of our accusers, who have projected their own dark thoughts onto our honest and well-intentioned motives.

9. Remember the Dick-and-Jane books and the first word you learned ... - LOOK. Pay attention to detail but do not miss the forest for the trees.

10. Share everything. Inspire others by being a mentor and in the process learn from them.

\section{References}

1. Darwin CR: On the Origin of Species by Means of Natural Selection. London, John Murray, 1859

2. Dawkins R: The Selfish Gene. Oxford, Oxford University Press, 1976

3. Fulghum R: All I Really Need to Know I Learned in Kindergarten. New York, Villard Books, 1990 